\title{
Fosfatets glemte betydning
}

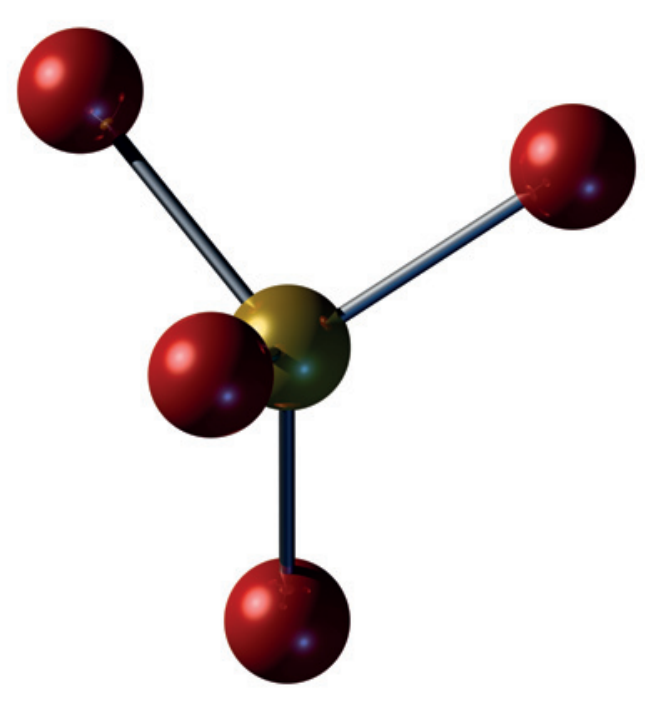

Illustrasjon Istockphoto
Hemoglobin er viktig og nødvendig for opptak av oksygen i lungene. 2,3 DPG (di-fosfor-glyserat) er nødvendig for å få frigjort oksygen på kapillarnivå. Forstadiet for 2,3 DPG er 1,3 DPG. For at kroppen skal danne 1,3 DPG er et visst minimum av fosfat nødvendig (1). 1,3 DPG er også forstadiet til danning av ATP (1). Glukosetilførsel til kroppen er viktig, men ved stort behov for energi vil store mengder glukose binde opp fosfat for å gjøre glukosen fettoppløselig. Frigjøring av store mengder glukose fra leveren kan bety det samme som en eventuell tilførsel av glukose per os. Typisk eksempel på glukosens uheldige virkning så man i 1945 da amerikanske soldater fant konsentrasjonsleire (2).

Disse fakta gjør at mine personlige og mange andres opplevelser kan forklares. Er man helt utkjørt, vil en tilførsel av fosfat og glukose etter 3-4 minutter bevirke at man er uthvilt og kan starte igjen. Når man slutter hardt arbeid eller trening, vil inntak av fosfat og glukose gjøre at man dagen etter ikke føler stølhet, dette til tross for manglende uttøying av muskler.

\section{Andreas Skulberg sr \\ Oslo}

Andreas Skulberg (f. 1924) er dr.med. og var tidligere anestesilege ved Ullevål sykehus i 30 år, sjeflege samme sted 1988-90. Han var ansvarlig for medisinsk opplæring av ambulansepersonell i Oslo 1976-88.

Ingen oppgitte interessekonflikter.

\section{Litteratur}

1. Lau K. Phosphate disorders. I: Kokko JK, Tannen $\mathrm{RL}$, red. Fluids and electrolytes. London: W.B. Saunders, 1986: 424-5

2. Skulberg A. Glucose - a potential killer. Acta Anaesthesiol Scand 2009; 53: 684.

Mottatt 26.9. 2011 og godkjent 3.11. 2011. Medisinsk redaktør Anne Kveim Lie.

Engelsk oversettelse av innlegget på www.tidsskriftet.no 